\title{
Intrinsic Hydration of Monopositive Uranyl Hydroxide, Nitrate, and Acetate Cations
}

\author{
Winnie Chien, Victor Anbalagan, Melvin Zandler, \\ and Michael Van Stipdonk \\ Department of Chemistry, Wichita State University, Wichita, Kansas, USA \\ Dorothy Hanna \\ Department of Chemistry, Kansas Wesleyan University, Salina, Kansas, USA \\ Garold Gresham and Gary Groenewold \\ Idaho National Engineering and Environmental Laboratory, Idaho Falls, Idaho, USA
}

The intrinsic hydration of three monopositive uranyl-anion complexes $\left(\mathrm{UO}_{2} \mathrm{~A}\right)^{+}$(where $\mathrm{A}=$ acetate, nitrate, or hydroxide) was investigated using ion-trap mass spectrometry (IT-MS). The relative rates for the formation of the monohydrates $\left[\left(\mathrm{UO}_{2} \mathrm{~A}\right)\left(\mathrm{H}_{2} \mathrm{O}\right)\right]^{+}$, with respect to the anion, followed the trend: Acetate $\geq$ nitrate $\gg$ hydroxide. This finding was rationalized in terms of the donation of electron density by the strongly basic $\mathrm{OH}^{-}$to the uranyl metal center, thereby reducing the Lewis acidity of $U$ and its propensity to react with incoming nucleophiles, viz., $\mathrm{H}_{2} \mathrm{O}$. An alternative explanation is that the more complex acetate and nitrate anions provide increased degrees of freedom that could accommodate excess energy from the hydration reaction. The monohydrates also reacted with water, forming dihydrates and then trihydrates. The rates for formation of the nitrate and acetate dihydrates $\left[\left(\mathrm{UO}_{2} \mathrm{~A}\right)\left(\mathrm{H}_{2} \mathrm{O}\right)_{2}\right]^{+}$ were very similar to the rates for formation of the monohydrates; the presence of the first $\mathrm{H}_{2} \mathrm{O}$ ligand had no influence on the addition of the second. In contrast, formation of the [ $\left.\left(\mathrm{UO}_{2} \mathrm{OH}\right)\left(\mathrm{H}_{2} \mathrm{O}\right)_{2}\right]^{+}$was nearly three times faster than the formation of the monohydrate. (J Am Soc Mass Spectrom 2004, 15, 777-783) (C) 2004 American Society for Mass Spectrometry

$\mathrm{T}$ The speciation and reactivity of uranium is a topic of sustained interest because species dependent chemistry [1] controls processes ranging from nuclear fuel processing [2] to mobility and fate in the geologic subsurface $[3,4]$. The solution chemistry of uranium is dominated by the uranyl ion, $\mathrm{UO}_{2}^{2+}$, for which recent theoretical studies [5-8] have suggested that strong interactions between the cation and solvent molecules, with significant charge transfer, cause the solvating species to behave like equatorial ligands. Therefore, specific interaction with solvent is likely to influence the physico-chemical behavior of the uranyl ion and its complexes in the environment. Unfortunately, explicit control over the interactions of solvent and non-solvent ligands with the uranyl ion is difficult, which makes the study of species-dependent uranium behavior complicated. To gain a better understanding of the intrinsic interactions between different uranium

Published online April 2, 2004

Address reprint requests to Dr. M. J. Van Stipdonk, Department of Chemistry, Wichita State University, Wichita, KS 67260-0051, USA. E-mail: mike.vanstipdonk@Wichita.edu and Dr. Gary Groenewold, Idaho National Engineering and Environmental Laboratory, Idaho Falls, ID 83415-2208 species and solvent, we have turned to investigations of uranyl-anion complexes in the gas phase. Recent studies have shown that ion-trap mass spectrometry can be used to probe intrinsic metal and metal-complex chemistry by exposing metal species to reagent gases deliberately added to the ion trap [9-20], or to adventitious $\mathrm{H}_{2} \mathrm{O}$ present in the He bath gas used to collisionally cool ions and improve trapping efficiency [21-24]. Further motivating the present study is the fact that ion traps will shortly be used to characterize actinide speciation in samples from radioactive waste disposal sites, and a concise understanding of actinide behavior will be critical for correctly interpreting environmental data [25].

We recently demonstrated that electrospray ionization (ESI) and multiple stage tandem mass spectrometry (MS) can be used to generate and characterize "solvated", gas-phase complexes featuring the uranyl ion coordinated by hydroxide, nitrate or a series of alkoxides [26]. In the pilot study reported here, ESI was used to produce gas-phase ions from solutions containing uranyl nitrate or uranyl acetate in deionized $\mathrm{H}_{2} \mathrm{O}$. The dominant species generated by ESI were those having 
the general formula $\left[\left(\mathrm{UO}_{2} \mathrm{~A}\right)(\mathrm{S})_{n}\right]^{+}$, where A represents hydroxide, nitrate or acetate, $\mathrm{S}$ represents water or acetic acid and $1 \leq \mathrm{n} \leq 3$. Significantly, these three types of anions represent those most likely to be encountered in samples derived from subsurface locations containing interred waste uranium. Multiple collisioninduced dissociation (CID) stages were used to eliminate coordinating water and/or acetic acid ligands to leave the monopositive cationic species $\left(\mathrm{UO}_{2} \mathrm{~A}\right)^{+}$. These complex ions were then isolated and stored, with minimal ion activation, to react with adventitious $\mathrm{H}_{2} \mathrm{O}$ present in the ion-trap mass spectrometer for time periods ranging from $1 \mathrm{~ms}$ to $10 \mathrm{~s}$. From these experiments we have been able to determine relative intrinsic hydration tendencies for the complexes, which is an important step towards understanding the interactions between ligated uranium and solvent molecules.

\section{Experimental}

ESI-MS, multiple-stage CID and ion-molecule reactions were carried out using established procedures described elsewhere [22, 24, 26]. Briefly, ESI mass spectra were collected using a Finnigan LCQ-Deca ion-trap mass spectrometer (ThermoFinnigan Corporation, San Jose, CA). Uranyl nitrate or acetate solutions (1 $\mathrm{mM}$ in deionized $\mathrm{H}_{2} \mathrm{O}$ ) were infused into the ESI-MS instrument using the incorporated syringe pump at a flow rate of $3-5 \mu \mathrm{l} / \mathrm{min}$. The atmospheric pressure ionization stack settings for the LCQ (lens voltages, quadrupole and octapole voltage offsets, etc.) were optimized for maximum ion transmission to the ion trap mass analyzer by using the auto-tune routine within the LCQ Tune program. The spray needle voltage was maintained at $+5 \mathrm{kV}$ and the $\mathrm{N}_{2}$ sheath gas flow at 25 units (arbitrary to the LCQ instrument, corresponding to approximately $.375 \mathrm{l} / \mathrm{m}$ ). To ensure maximum yield of solvated uranyl cation complexes, the heated capillary temperature was maintained between 110 and $130^{\circ} \mathrm{C}$. Helium was used as the bath/buffer gas to improve trapping efficiency and as the collision gas for CID experiments.

CID was performed using isolation widths of 5-12 mass units (depending on the species), an activation $\mathrm{Q}$ (used to adjust the $q_{z}$ value for the resonant excitation of the precursor ion during the CID experiment) value of .3 , activation amplitudes of $10-20 \%$ (of $5 \mathrm{~V}$ ) and activation times of $30 \mathrm{~ms}$. Since the $q_{z}$ value influences the kinetic energies of the trapped ions, a constant value of was employed for studying dehydrated ions having different masses. The kinetic energy of the reactant ions is known to be inversely proportional to the rate of reaction [27], principally because the reverse reaction of the activated complex is speeded up, and we found this to be explicitly true in our previous study of dioxo uranium cations [28]. Even though the present studies were conducted at pressures where the reverse reactions were probably negligible, utilization of a constant $q_{z}$ value improves reaction comparability. For intrinsic hydration investigations, all charged species other than the uranyl complex of interest were resonantly ejected from the ion trap. For quantitative comparisons, the complex ions were isolated and stored within the ion trap for times ranging from 1 to $1000 \mathrm{~ms}$, to react with $\mathrm{H}_{2} \mathrm{O}$ present within the He bath gas. Following the isolation period, the precursor and product ions were scanned out of the trap and detected as part of the automated mass analysis operation.

Kinetic modeling of the addition of $\mathrm{H}_{2} \mathrm{O}$ to the uranyl-anion complexes was performed as follows. Fractional abundances of reactant and product ions were calculated by dividing the relative intensities of the precursor (complex) ion and adduct ions by the total ion abundance. The changes in fractional abundances with time were used to obtain relative values of the rate constants for the addition reactions using the Chemical Kinetic Simulator software package (CKS), available through a no cost license on the IBM website, which employs a stochastic algorithm to model the reacting system [29-32]. Reactions involved in the system were assumed to be kinetically simple, having rate equations based upon reaction stoichiometry. In reality, the water addition reactions are certainly ternary, i.e., the He bath gas serves to collisionally stabilize activated intermediates and eliminate back reactions. Thus, the temporal evolution of the reactant ion and adduct intensities indicated that our experiments were conducted under pseudo-first order reaction conditions [33]. Previous studies have confirmed that the concentration of water present in the ion trap is large compared with the concentrations of solvent and reactant ion species that enter during the ESI process [23]. Putative rate constants for the reactions in the model system were changed incrementally until the concentration curves generated by the model fit the observed fractional abundances. The concentration of $\mathrm{H}_{2} \mathrm{O}$ is a required input parameter for CKS and which was kept constant during all experiments. Although concentration of water molecules in our ion trap cannot be quantitatively determined, $\left[\mathrm{H}_{2} \mathrm{O}\right]$ was estimated at $\sim 8 \times 10^{10}$ molecules $\mathrm{cm}^{-3}$ (or half of the total pressure) based upon ambient conditions existing in the ion trap $(298 \mathrm{~K}$ and 5 $\times 10^{-6}$ torr). Uncertainty in our knowledge of $\left[\mathrm{H}_{2} \mathrm{O}\right]$ in these experiments is unquestionably the greatest contributor to the absolute uncertainty of our rate constant measurements. Hence the rate constant measurements are most appropriately used for relative comparisons within the constraints of this study. Nevertheless, the value measured for the reaction of $\left(\mathrm{UO}_{2} \mathrm{OH}\right)^{+}+\mathrm{H}_{2} \mathrm{O}$ was within $30 \%$ of the value independently measured using a different ion trap technique (vide infra) [28], which provides some confidence in the accuracy of the absolute $k$ values [23]. Furthermore, rate constants for the formation of the monohydrates calculated using CKS were consistent with the order of magnitude of maximum rate constants predicted using the average dipole orientation (ADO) theory [34-36], which has been successfully employed to interpret kinetic data for 
other chemical systems investigated using ion trap mass spectrometers [16, 17]. Rate constants calculated for the formation of the second and third hydrates were fairly insensitive to minor adjustments in the rate constants (5-20\%) but larger changes created significant deviation of the modeled concentration curves from the observed fractional abundances.

Precision in the rate constant measurements was dependent on the experimentally derived kinetic profiles; for trials conducted on the same day, the precision of individual ion abundances were on the order of $5-10 \%$ (relative standard deviation), and all trends were fully reproducible in five separate trials. Rate constant precision was bounded by calculating maximum and minimum values for the initial hydration reactions from "bootstrapped" data sets generated by incorporating abundance values from individual data sets that showed the largest variations. These analyses showed a maximum deviation of $\sim 9 \%$ compared with the average values reported herein.

Preliminary ab-initio calculations were performed using the Gaussian 98 group of programs [37]. Our principal interest was in the lowest energy conformation of the uranyl-anion trihydrate complexes rather than absolute energy, enthalpy and free energy values. The complexes were optimized using density functional theory calculations and the B3LYP-SDD basis set. To test the general accuracy of the calculations for the determination of most-probable complex geometry, conformations of tetrahydrated, $\left[\mathrm{UO}_{2}\left(\mathrm{H}_{2} \mathrm{O}\right)_{4}\right]^{2+}$, and pentahydrated, $\left[\mathrm{UO}_{2}\left(\mathrm{H}_{2} \mathrm{O}\right)_{5}\right]^{2+}$, uranyl ion were modeled. The lowest energy conformations for both species, as generated using the B3LYP-SDD basis set, matched those reported in previous studies of similar systems using other basis sets $[5,7]$.

\section{Results and Discussion}

Figure 1 shows the kinetic profiles for the intrinsic hydration of (Figure 1a) $\left(\mathrm{UO}_{2} \mathrm{OH}\right)^{+}$, (Figure 1b) $\left(\mathrm{UO}_{2} \mathrm{NO}_{3}\right)^{+}$, and (Figure 1c) $\left(\mathrm{UO}_{2} \mathrm{CH}_{3} \mathrm{CO}_{2}\right)^{+}$: in all three examples, decreasing precursor ion abundance was accompanied by increases in the abundance of species representing the addition of a first, second and third $\mathrm{H}_{2} \mathrm{O}$ ligand. The addition of a fourth $\mathrm{H}_{2} \mathrm{O}$ ligand was not observed, even for isolation times of $10 \mathrm{~s}$. As noted in the Experimental section, the kinetics of the systems were successfully modeled by assuming that the reactions were kinetically simple, irreversible additions, having rate equations based upon reaction stoichiometry. The reaction schemes used for kinetic modeling and associated pseudo-first order rate constants are shown below.

$$
\begin{aligned}
& \left(\mathrm{UO}_{2} \mathrm{~A}\right)^{+}+\mathrm{H}_{2} \mathrm{O} \rightarrow\left[\left(\mathrm{UO}_{2} \mathrm{~A}\right)\left(\mathrm{H}_{2} \mathrm{O}\right)\right]^{+} \quad k_{1} \\
& \left.\left(\mathrm{UO}_{2} \mathrm{~A}\right)\left(\mathrm{H}_{2} \mathrm{O}\right)\right]^{+} \mathrm{H}_{2} \mathrm{O} \rightarrow\left[\left(\mathrm{UO}_{2} \mathrm{~A}\right)\left(\mathrm{H}_{2} \mathrm{O}\right)_{2}\right]^{+} \quad k_{2}
\end{aligned}
$$

(a)

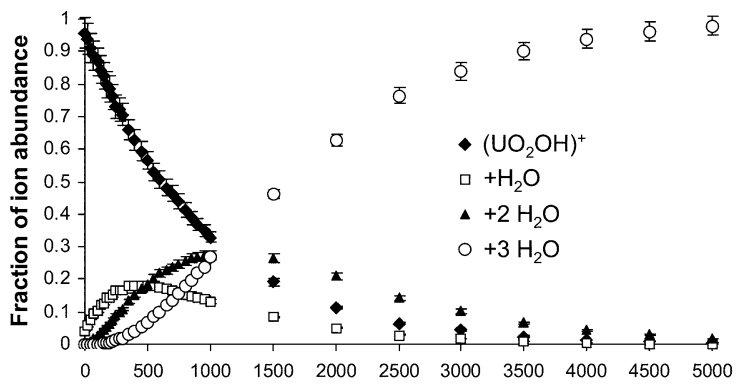

(b)

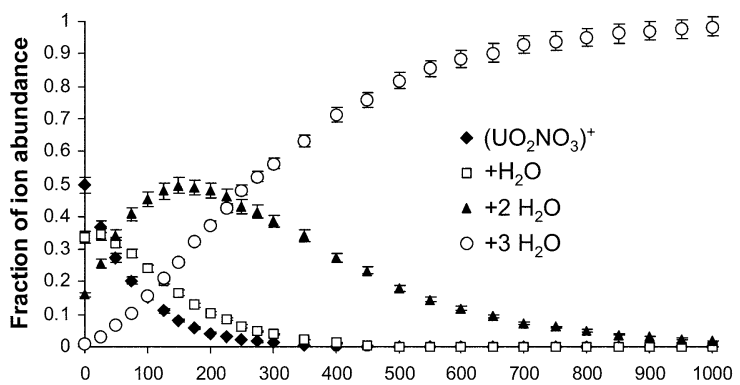

(c)

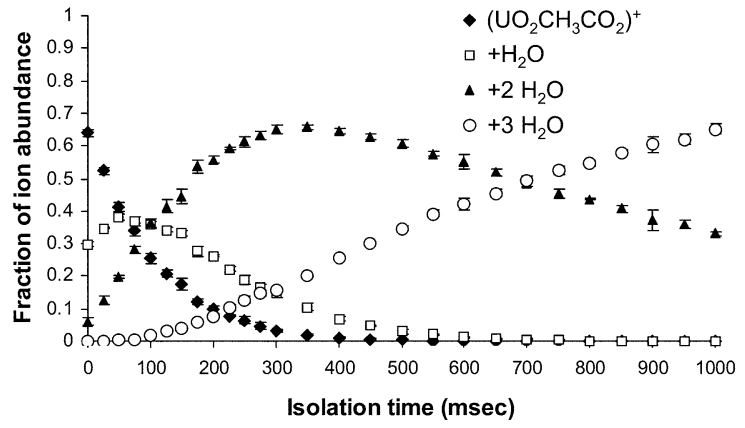

Figure 1. Kinetic profiles for the intrinsic hydration of (a) $\left(\mathrm{UO}_{2} \mathrm{OH}\right)^{+}$, (b) $\left(\mathrm{UO}_{2} \mathrm{NO}_{3}\right)^{+}$, and (c) $\left(\mathrm{UO}_{2} \mathrm{CH}_{3} \mathrm{CO}_{2}\right)^{+}$. Note differences in isolation time scales. Error bars represent the sample standard deviation $(\sigma)$ from a minimum of three experimental trials conducted on the same day.

$$
\left.\left(\mathrm{UO}_{2} \mathrm{~A}\right)\left(\mathrm{H}_{2} \mathrm{O}\right)_{2}\right]^{+} \mathrm{H}_{2} \mathrm{O} \rightarrow\left[\left(\mathrm{UO}_{2} \mathrm{~A}\right)\left(\mathrm{H}_{2} \mathrm{O}\right)_{3}\right]^{+} \quad k_{3}
$$

The fact that reaction 1 for the hydroxide required no reverse reaction deserves comment, because a previous study [28] of $\left(\mathrm{UO}_{2} \mathrm{OH}\right)^{+}$hydration by our groups using an ion trap-secondary ion mass spectrometer (IT-SIMS) emphatically indicated that significant back reactions were necessary to computationally replicate the observed kinetic profiles. These different observations are most probably reconciled by the fact that the uranyl species in the IT-SIMS experiments were reacting at pressures at least an order of magnitude lower than in the present ESI-MS experiments, and as a result were not completely thermalized. (Recent studies [38, 39] suggest that the buffer gas in the ion trap can assist in the dissipation of excess reaction energy, consistent with the observations made here). However, the kinetic treatment of the IT-SIMS experiments resulted in explicit rate constants for both the forward and reverse reactions, which enables comparison of the $k_{1}$ values measured in the two experiments. The value of $3 \times$ 
Table 1. Rate constants calculated hydration reactions involving the hydroxide, nitrate and acetate containing uranyl complexes. Estimated precision on rate constants is $5-10 \%$

\begin{tabular}{|c|c|c|c|c|c|c|c|c|c|}
\hline \multirow[b]{2}{*}{ Anion } & \multicolumn{3}{|c|}{ Modeled } & \multicolumn{3}{|c|}{ ADO } & \multicolumn{3}{|c|}{$\%$ Efficiency } \\
\hline & $k_{1}$ & $k_{2}$ & $k_{3}$ & $k_{1}$ & $k_{2}$ & $k_{3}$ & $k_{1}$ & $k_{2}$ & $k_{3}$ \\
\hline $\mathrm{CH}_{3} \mathrm{COO}^{-}$ & $4.0 \times 10^{-10}$ & $3.8 \times 10^{-10}$ & $6.0 \times 10^{-11}$ & $2.13 \times 10^{-9}$ & $2.13 \times 10^{-9}$ & $2.13 \times 10^{-9}$ & 19 & 18 & 2.8 \\
\hline $\mathrm{NO}_{3}^{-}$ & $3.5 \times 10^{-10}$ & $3.8 \times 10^{-10}$ & $1.3 \times 10^{-10}$ & $2.13 \times 10^{-9}$ & $2.13 \times 10^{-9}$ & $2.12 \times 10^{-9}$ & 16 & 18 & 6.1 \\
\hline $\mathrm{OH}^{-}$ & $2.9 \times 10^{-11}$ & $9.9 \times 10^{-11}$ & $4.6 \times 10^{-11}$ & $2.14 \times 10^{-9}$ & $2.14 \times 10^{-9}$ & $2.13 \times 10^{-9}$ & 1.4 & 4.6 & 2.2 \\
\hline
\end{tabular}

$10^{-11} \mathrm{~cm}^{3} \mathrm{~s}^{-1}$ molecule ${ }^{-1}$ measured here using the ESI-MS is in good agreement with the value of $4 \times 10^{-11}$ $\mathrm{cm}^{3} \mathrm{~s}^{-1}$ molecule ${ }^{-1}$ measured previously using the ITSIMS [33].

Computed rate constants for the addition of the first $\mathrm{H}_{2} \mathrm{O}$ ligand were found to decrease in the order $\left(\mathrm{UO}_{2} \mathrm{CH}_{3} \mathrm{COO}\right)^{+} \geq\left(\mathrm{UO}_{2} \mathrm{NO}_{3}\right)^{+} \gg\left(\mathrm{UO}_{2} \mathrm{OH}\right)^{+}$, and were greater by a factor of $\sim 10$ for the acetate and nitrate containing complexes relative to the hydroxide version. Within experimental error, rate constants for subsequent addition of a second $\mathrm{H}_{2} \mathrm{O}$ ligand did not change significantly for $\left(\mathrm{UO}_{2} \mathrm{NO}_{3}\right)^{+}$and $\left(\mathrm{UO}_{2} \mathrm{CH}_{3} \mathrm{COO}\right)^{+}$. In contrast to the behavior observed for nitrate and acetate, addition of the second $\mathrm{H}_{2} \mathrm{O}$ ligand to $\left(\mathrm{UO}_{2} \mathrm{OH}\right)^{+}$ was $>3$ times faster than addition of the first $\mathrm{H}_{2} \mathrm{O}$ (again in close agreement with the results of the recent IT-SIMS study [28]). Rate constants for the addition of the third $\mathrm{H}_{2} \mathrm{O}$ ligand were lower (relative to the constants for the addition of the second $\mathrm{H}_{2} \mathrm{O}$ ) by factors of $\sim 2,3$, and 6 for $\left(\mathrm{UO}_{2} \mathrm{OH}\right)^{+}, \quad\left(\mathrm{UO}_{2} \mathrm{NO}_{3}\right)^{+}$and $\left(\mathrm{UO}_{2} \mathrm{CH}_{3} \mathrm{COO}\right)^{+}$respectively. To the best of our knowledge, this is the first demonstration that the relative intrinsic hydration tendencies of the uranyl ion complexed by common inorganic and organic anions.

The dependency of rates of formation of ion-molecule complexes in the gas phase upon intrinsic factors such as the masses of the species involved, ionic charge, molecular polarizability and molecular dipole moment has been quantified using reparameterized averagedipole-orientation (ADO) theory [34-36]. ADO theory has been used to predict capture rate constants, which provide the maximum value for the reaction rate constants of ion/molecule reactions occurring in the gas phase. Calculated capture rate constants for the sequential hydration of the uranyl complexes are shown in Table 1 . The change in percent efficiency of the hydration reactions may be qualitatively interpreted as a measure of the aggregate contribution of several factors to the hydration behavior of the complexes. These include the ability of the complex to distribute excess energy from reactive collisions, the electronic influence of existing ligands on the ion's ability to attract and bond additional ligands, and the influence of geometry and intramolecular interactions on complex stability.

The basicities of the anionic ligands increase in the order $\mathrm{NO}_{3}^{-}<\mathrm{CH}_{3} \mathrm{COO}^{-}<\mathrm{OH}^{-}$. Total $\mathrm{e}^{-}$density around the metal center of the uranyl complex is expected to increase with increasing basic strength of the anionic ligand. The magnitudes of the stability constants for the uranyl-anion complexes [40] are consistent with this expectation. Also, the $\mathrm{O}=\mathrm{U}=\mathrm{O}$ symmetrical Raman stretching frequencies decrease with increasing basicity of the anion, indicating a weakening of the $\mathrm{U}=\mathrm{O}$ bonds as the basic strength of the anion increases [7, 40, 41], and consistent with increased electron density being present at the metal center. For the formation of the $\left[\left(\mathrm{UO}_{2} \mathrm{~A}\right) \mathrm{H}_{2} \mathrm{O}\right]^{+}$complexes, our results demonstrate that the hydration tendency is lowest for the most basic ligand i.e., $\left(\mathrm{UO}_{2} \mathrm{OH}\right)^{+}$. However, only a weak correlation between anion basicity and hydration rate was observed for $\left(\mathrm{UO}_{2} \mathrm{NO}_{3}\right)^{+}$versus $\left(\mathrm{UO}_{2} \mathrm{CH}_{3} \mathrm{CO}_{2}\right)^{+}$, and their monohydrates, suggesting that other factors may significantly influence the initial intrinsic hydration tendencies of these complexes. Additional degrees of freedom (df) within nitrate and acetate could distribute excess energy from reactive collisions within the molecule and stabilize the nascent uranyl-anion-water complex, which would result in greater hydration reactivity of complexes containing these anions relative to the $\mathrm{OH}^{-}$complex. Our earlier study showed that multiple-stage CID of alcohol-coordinated uranyl nitrate will generate monopositive uranyl alkoxides [24] via the elimination of $\mathrm{HNO}_{3}$. Preliminary studies of intrinsic hydration indicate that, relative to uranyl hydroxide, the rate constants for the formation of the monohydrate to the methoxide, ethoxide, $n$-propoxide and $n$-butoxide increase by factors of $\sim 5,14,30$, and 34, respectively [38]. The rate constants for the formation of the di and trihydrates also increase with the size and complexity of the alkyl group of the alkoxide. Similar results have been observed in preliminary investigation of the intrinsic hydration of uranyl acetate, propanoate and butanoate (i.e., the rates, in general, increase with the size and complexity of the carboxy anion). Taken together, the results suggest a positive influence on hydration rate by increased df. Attempts to generate monopositive cations containing chloride, bromide and iodide failed as the precursor complex ions eliminate $\mathrm{HCl}, \mathrm{HBr}$, and $\mathrm{HI}$ to generate $\left(\mathrm{UO}_{2} \mathrm{OH}\right)^{+}$.

In general, hydration rates would be expected to decrease as the number of water molecules coordinated to the uranyl-anion complex increases, due to increased electron density transferred to the U(VI) ion; therefore, the increase in $k_{2}$ relative to $k_{1}$ observed for $\left(\mathrm{UO}_{2} \mathrm{OH}\right)^{+}$ is of particular interest. The larger value for $k_{2}$, which describes addition of $\mathrm{H}_{2} \mathrm{O}$ to $\left[\left(\mathrm{UO}_{2} \mathrm{OH}\right)\left(\mathrm{H}_{2} \mathrm{O}\right)\right]^{+}$, supports the hypothesis that additional $\mathrm{df}$ are important for 
stabilizing the nascent adducts, because the monohydrate has additional df compared with $\left(\mathrm{UO}_{2} \mathrm{OH}\right)^{+}$. On the other hand, intramolecular hydrogen bonding might increase stabilization of the nascent $\left[\left(\mathrm{UO}_{2} \mathrm{OH}\right)\left(\mathrm{H}_{2} \mathrm{O}\right)\right]^{+}$complex, and previous modeling studies have shown such intramolecular interactions influence the preferred geometries of gas phase complexes [42]. However, calculated structures for the stable, hydrated hydroxyuranyl complexes do not appear to support this (vide infra). It is worthwhile noting that the relative ordering of the rate constants mirrors earlier studies of hydrate thermodynamics for first row transition metal monocations $\mathrm{M}^{+}$, which showed that the bond energy for the second water molecule was $\geq$ that of the first [43-48]; since this trend was not observed for alkali metals, it was rationalized in terms of orbital rehybridization. Since orbital rehybridization is also significant in the uranyl system [41], measurement of bond energies for the three $\mathrm{H}_{2} \mathrm{O}$ molecules attached to $\left(\mathrm{UO}_{2} \mathrm{OH}\right)^{+}$is needed, but cannot be accomplished using the present experimental setup.

Regardless of the coordinating anion, the uranyl complexes investigated here accepted a maximum of 3 $\mathrm{H}_{2} \mathrm{O}$ ligands. Work by Vachet and Callahan suggested that the nitrate and acetate anions, within gas-phase transition metal complexes, are primarily bidentate ligands [11]. The acceptance of $3 \mathrm{H}_{2} \mathrm{O}$ ligands by $\left(\mathrm{UO}_{2} \mathrm{NO}_{3}\right)^{+}$and $\left(\mathrm{UO}_{2} \mathrm{CH}_{3} \mathrm{CO}_{2}\right)^{+}$is consistent with the formation of gas-phase complexes with pentagonal bipyramidal conformation, with two equatorial coordination sites occupied by $\mathrm{O}$ atoms of the anions, reminiscent of the structures of uranyl complexes in solution [1-3] and generated computationally [5] To evaluate this possibility, density functional theory (DFT) calculations using the B3LYP-SDD basis set were conducted. The octahedral structure of $\left[\left(\mathrm{UO}_{2} \mathrm{OH}\right)\left(\mathrm{H}_{2} \mathrm{O}\right)_{3}\right]^{+}$had been recently calculated by Oda and Aoshima [7], and was repeated here to evaluate the approach. The minimized structure had an axial $\mathrm{U}=\mathrm{O}$ bond distance of $1.799 \AA$, which was in excellent agreement with the previously reported values for hydroxy-uranyl complexes $[7,8,49]$. The equatorial $\mathrm{U}-\mathrm{OH}$ bond $(2.04 \AA)$ was $0.05 \AA$ shorter than the value calculated by Oda and Aoshima, and the equatorial $\mathrm{U}-\mathrm{OH}_{2}$ bond lengths (2.44-2.47 $\AA$ ) were $\sim 0.1 \AA$ shorter. These variations are not particularly surprising since a different basis was used, and Oda noted minor variations depending on the basis set employed. This comparison provided some validation for the computational approach $[7,40,41]$.

Calculations generated two energetically competitive conformations for each of the trihydrate complexes containing uranyl nitrate and acetate (Figure 2). The axial $\mathrm{U}=\mathrm{O}$ bond length was $1.780 \AA$ for these complexes; this value was shorter than that for the hydroxy complex, consistent with earlier studies [7, 40,41]. The lowest energy conformation for hydrated $\left.\left(\mathrm{UO}_{2} \mathrm{NO}_{3}\right)\right]^{+}$ included the nitrate ligand as bidentate with respect to $\mathrm{U}$. The $\mathrm{H}_{2} \mathrm{O}$ ligands are oriented vertically (parallel to the axis of the uranyl ion), in accord with structures for
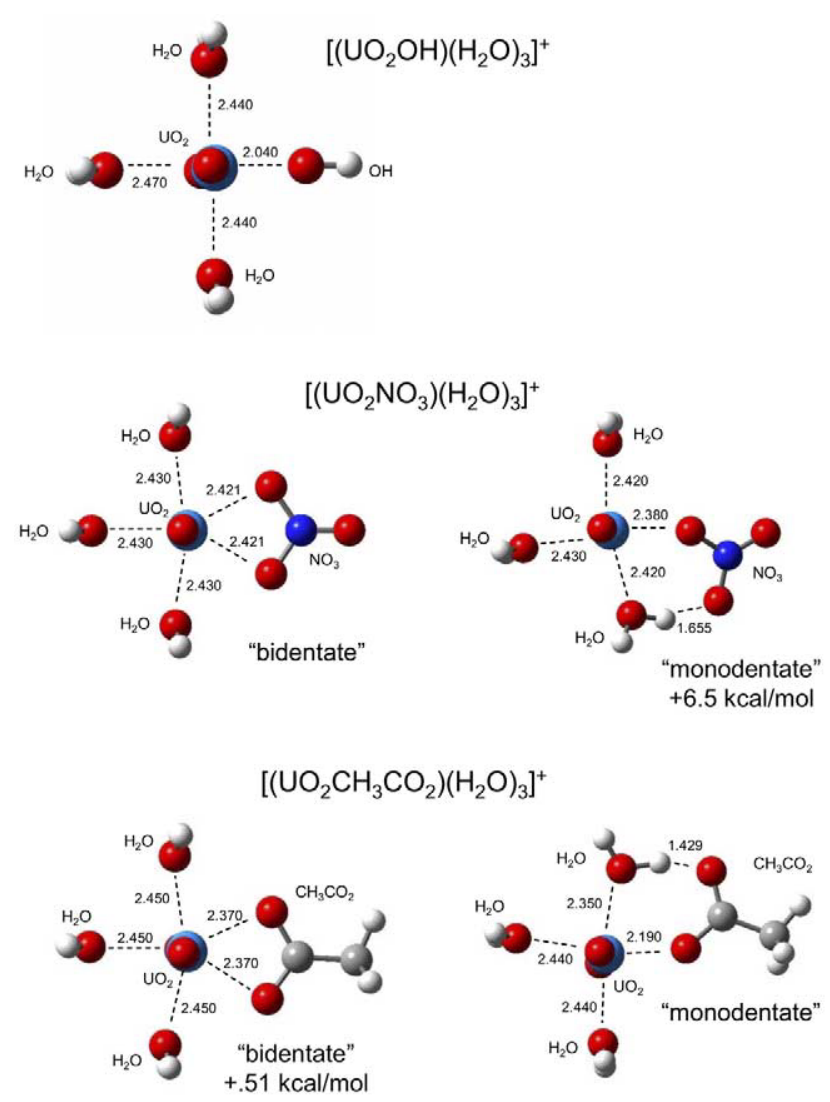

Figure 2. Conformations of the monopositive, trihydrate uranylanion complexes resulting from DFT calculations using the B3LYP-SDD basis set. Views are "top-down" to better show ligand coordination in the equatorial positions of the uranyl ion. Bond lengths provided are in Angstroms.

hydrated $\mathrm{UO}_{2}^{2+}$ reported earlier [5, 7]. A second stable conformation was identified in which the nitrate ion is monodentate with respect to U; this was ca. $6.5 \mathrm{kcal} /$ mol higher in energy, and involved a hydrogen bond between nitrate and one $\mathrm{H}_{2} \mathrm{O}$ ligand. The calculations suggested that the monodentate conformation for hydrated $\left(\mathrm{UO}_{2} \mathrm{CH}_{3} \mathrm{CO}_{2}\right)^{+}$is lowest energy, but that the mono- and bidentate conformations differed by only $\sim .5 \mathrm{kcal} / \mathrm{mol}$. The fact that the monodentate structure is more stable in the case of $\left(\mathrm{UO}_{2} \mathrm{CH}_{3} \mathrm{CO}_{2}\right)^{+}$is likely attributable to a strong hydrogen bond between acetate and a rotated cis $-\mathrm{H}_{2} \mathrm{O}$ ligand, in which a $\mathrm{H}$ atom is within $1.429 \AA$ of the carbonyl oxygen atom. The uranyl acetate complex is presumably capable of converting to a conformation that includes coordination at only four equatorial sites, which together with the fact that the hydrated uranyl hydroxide complex contains fewer than five equatorial ligands, shows that the acceptance of an additional $\mathrm{H}_{2} \mathrm{O}$ ligand to complete the coordination sphere does not occur readily under the gas-phase.

In summary, the results of this study indicate that the intrinsic hydration of monopositive uranyl-ligand complexes is markedly influenced by the nature of the coordinating ligand. The experimental approach thus provides an avenue for understanding ligation of $\mathrm{UO}_{2}^{2+}$ 
complexed with other anions such as phosphates, polycarboxylates, and silicates that are important in industrial and environmental processes. Future experimental and theoretical studies of these systems will further clarify the preferred geometries of the complexes, the extent to which degrees of freedom in the anion and intramolecular hydrogen bonding contribute to stabilization of the collision complexes. Systematic variation of the Lewis and Bronsted acid/base properties of the ligands are underway, which should enable discernment of the relative roles of ligand basicity, degrees of freedom, and intramolecular hydrogen bonding in fostering solvent interactions. We are also currently pursuing the production of analogous doubly and singly charged uranyl complexes (i.e., similar composition and coordination number/structure) to facilitate an investigation of the influence of overall complex charge state on hydration tendency.

\section{Acknowledgments}

MVS acknowledges support from the National Science Foundation (CAREER-0239800), the Kansas Technology Enterprise Corporation/Kansas NSF EPSCoR program, and a subcontract from the U.S. Department of Energy through the INEEL Institute. DH acknowledges the support of the Wichita State University Research Sites for Educators in Chemistry program sponsored by the National Science Foundation. GSG and GLG acknowledge support by the U.S. Department of Energy, Environmental Systems Research Program, under contract DE-AC-07-99ID13727. Funds for the purchase of the LCQ-Deca instrument were provided by the Kansas NSF EPSCoR program and the Wichita State University College of Liberal Arts and Sciences.

\section{References}

1. Weigel, F. Uranium. In The Chemistry of the Actinide Elements; Katz, J. J.; Morss, L. R.; Seaborg, G. T., Eds.; Chapman and Hall: London, 1986; p 169.

2. Greenwood, N. N.; Earnshaw, A. Chemistry of the Elements, 2nd ed.; Butterworth Heinemann: Oxford, Great Britain, 1997; p 1250.

3. Murphy, W. M.; Schock, E. L. Environmental Aqueous Geochemistry of Actinides. In Uranium: Mineralogy, Geochemistry, and the Environment; Burns, P. C.; Finch, R., Eds.; Mineralogical Society of America: Washington, D.C., 1999; p 221-254.

4. Brookins, D. G. Geochemical Aspects of Radioactive Waste Disposal; Springer-Verlag: New York, 1984; p 211.

5. Spencer, S.; Gagliardi, L.; Handy, N. C.; Ioannou, A. G.; Skylaris, C.-K.; Willetts, A.; Simper, A. M. Hydration of $\mathrm{UO}_{2}^{2+}$ and $\mathrm{PuO}_{2}^{2+}$. J. Phys. Chem. A 1999, 103, 1831-1837.

6. Clavaguera-Sarrio, C.; Brenner, V.; Hoyau, S.; Marsden, C. J.; Millie, P.; Dognon, J.-P. Modeling of Uranyl-Cation-Water Clusters. J. Phys. Chem. B 2003, 107, 3051-3060.

7. Oda, Y.; Aoshima, A. Ab Initio Quantum Chemical Study on Charge Distribution and Molecular Structure of Uranyl (VI) Species with Raman Frequency. J. Nuc. Sci. Technol. 2002, 39, 647-654.

8. Tsushima, S.; Reich, T. A Theoretical Study of Uranyl Hydroxide Monomeric and Dimeric Complexes. Chem. Phys. Lett. 2001, 347, 127-132.

9. Vachet, R. W.; Hartman, J. A. R.; Callahan, J. H. Ion-Molecule Reactions in a Quadrupole Ion Trap as a Probe of the Gas- phase Structure of Metal Complexes. J. Mass Spectrom. 1998, $33,1209-1225$.

10. Hartman, J. R.; Vachet, R. W.; Callahan, J. H. Gas, Solution, and Solid State Coordination Environments for the Nickel(II) Complexes of a Series of Aminopyridine Ligands of Varying Coordination Number. Inorg. Chim. Acta 2000, 297, 79-87.

11. Vachet, R. W.; Callahan, J. H. Quadrupole Ion Trap Studies of the Structure and Reactivity of Transition Metal Ion Pair Complexes. J. Mass Spectrom. 2000, 35, 311-320.

12. Vachet, R. W.; Hartman, J. R.; Gertner, J. W.; Callahan, J. H. Investigation of Metal Complex Coordination Structure Using Collision-Induced Dissociation and Ion-Molecule Reactions in a Quadrupole Ion Trap Mass Spectrometer. Int. J. Mass Spectrom. 2001, 204, 101-112.

13. Combariza, M. Y.; Vachet, R. W. Gas-Phase Ion-Molecule Reactions of Transition Metal Complexes: The Effect of Different Coordination Spheres on Complex Reactivity. J. Am. Soc. Mass Spectrom. 2002, 13, 813-825.

14. Wu, H. F.; Brodbelt, J. S. Gas-Phase Chelation Reactions of Monopositive Cations with Heteroaromatic Ligands. Inorg. Chem. 1995, 34, 615-621.

15. Scott, J. R.; Groenewold, G. S.; Gianotto, A. K.; Benson, M. T.; Wright, J. B. Experimental and Computational Study of Hydration of Reactions of Aluminum Oxide Anion Clusters. J. Phys. Chem. A 2000, 104, 7079-7090.

16. Groenewold, G. S.; Hodges, B. D. M.; Scott, J. R.; Gianotto, A. K.; Appelhans, A. D.; Kessinger, G. F.; Wright, J. B. Oxygen-for-Sulfur Exchange in the Gas Phase: Reactions of $\mathrm{Al}$ and Si Oxyanions with $\mathrm{H}_{2} \mathrm{~S}$. J. Phys. Chem. A 2001, 105, 4059-4064.

17. Groenewold, G. S.; Scott, J. R.; Gianotto, A. K.; Hodges, B. D. M.; Kessinger, G. F.; Benson, M. T.; Wright, J. B. Gas-Phase Condensation Reactions of $\mathrm{Si}_{\mathrm{x}} \mathrm{O}_{\mathrm{y}} \mathrm{H}_{\mathrm{z}}^{-}$Oxyanions with $\mathrm{H}_{2}$ O. J. Chem. Phys. A 2001, 105, 9681-9688.

18. Gianotto, A. K.; Hodges, B. D. M.; Benson, M. T.; Harrington, P. d. B.; Appelhans, A. D.; Olson, J. E.; Groenewold, G. S. Ion-Molecule Reactions of Gas-Phase Chromium Oxyanions: $\mathrm{Cr}_{\mathrm{x}} \mathrm{O}_{\mathrm{y}} \mathrm{H}_{\mathrm{z}}^{-}+\mathrm{H}_{2} \mathrm{O}$. J. Phys. Chem. A 2003, 107, 5948-5955.

19. Innorta, G.; Torroni, S.; Foffani, A.; Pontoni, L. A Revisitation of the Gaseous Ion Chemistry of Ferrocene. J. Mass Spectrom. 1995, 30, 1633-1635.

20. Operti, L.; Splendore, M.; Vaglio, G. A.; Franklin, A. M.; Todd, J. F. J. Investigation of the Complex-Reactions of $\mathrm{SiH}_{4}$ and $\mathrm{GeH}_{4}$ in the Ion-Trap Using Dynamically Programmed Scanning. Int. J. Mass Spectrom. Ion Processes 1994, 136, $25-33$.

21. Perera, B. A.; Ince, M. P.; Talaty, E. R.; Van Stipdonk, M. J. Gas Phase Attachment of Water and Methanol to Ag(I) Complexes with $\alpha$-Amino Acids in an Ion Trap Mass Spectrometer. Rapid Commun. Mass Spectrom. 2001, 15, 615-622.

22. Perera, B. A.; Gallardo, A. L.; Barr, J. M.; Tekarli, S. M.; Anbalagan, V.; Talaty, E. R.; Van Stipdonk, M. J. Influence of a Ring Substituent on the Tendency to Form $\mathrm{H}_{2} \mathrm{O}$ adducts to $\mathrm{Ag}^{+}$Complexes with Phenylalanine Analogues in an Ion Trap Mass Spectrometer. J. Mass Spectrom. 2002, 37, 401-413.

23. Talaty, E. R.; Perera, A. B.; Gallardo, A. L.; Barr, J. M.; Van Stipdonk, M. J. Elucidation of Fragmentation Pathways for the Collision Induced Dissociation of the Binary $\mathrm{Ag}(\mathrm{I})$ Complex with Phenylalanine. J. Phys. Chem. A 2001, 105, 8059-5068.

24. Hanna, D.; Silva, M.; Morrison, J.; Tekarli, S.; Anbalagan, V.; Van Stipdonk, M. J. Gas-Phase Hydration and Alcohol Addition Reactions of Complexes Composed of $\mathrm{Ag}^{+}$and a Single Alcohol Molecule. J. Phys. Chem. A 2003, 107, 5528-5537.

25. Groenewold, G. S., Fox, R. V., Hull, L. C. Test Plan for the Study of OU 7-13/14 Soil and Waste Material Samples Obtained from the OU 7-10 Glovebox Excavator Method Project; United States Department of Energy Report, Idaho National Engineering 
and Environmental Laboratory, INEEL/EXT-03-00759: Idaho Falls, ID, September, 2003.

26. Van Stipdonk, M. J.; Gresham, G.; Groenewold, G.; Anbalagan, V.; Hanna, D.; Chien, W. Elucidation of the Collision Induced Dissociation Pathways of Water and Alcohol Coordinated Complexes Containing the Uranyl Cation. J. Am. Soc. Mass Spectrom. 2003, 14, 1205-1214.

27. McLuckey, S. A.; Reid, G. E.; Wells, J. M. Ion Parking During Ion/Ion Reactions in Electrodynamic Ion Traps. Anal. Chem. 2002, 74, 336-346.

28. Gresham, G. L.; Gianotto, A. K.; Harrington, P. d. B.; Cao, L.; Scott, J. R.; Olson, J. E.; Appelhans, A. D.; Van Stipdonk, M. J.; Groenewold, G. S. Gas-Phase Hydration of U(IV), U(V), and U(VI) Dioxo Monocations. J. Phys. Chem. A 2003, 107, 85308538.

29. Gillespie, D. T. A General Method for Numerically Simulating the Stochastic Time Evolution of Coupled Chemical Reactions. J. Comput. Phys. 1976, 22, 403-434.

30. Gillespie, D. T. Exact Stochastic Simulation of Coupled Chemical Reactions. J. Phys. Chem. 1977, 81, 2340-2362.

31. Houle, F. A.; Hinsberg, W. D. Stochastic Simulations of Temperature Programmed Desorption Kinetics. Surf. Sci. 1995, $338,329-346$.

32. Hinsberg, W. D., Houle, F. A. Chemical Kinetics Simulator Version 1.01.

33. Weishaar, J. C. Bare Transition Metal Atoms in the Gas Phase: Reactions of $\mathrm{M}, \mathrm{M}^{+}$, and $\mathrm{M}^{2+}$ with Hydrocarbons. Acc. Chem. Res. 1993, 26, 213-219.

34. Su, T.; Chesnavich, W. J. Parametrization of the Ion-Polar Molecule Collision Rate Constant by Trajectory Calculations. J. Chem. Phys. 1982, 76, 5183-5185.

35. Su, T.; Bowers, M. T. Parameterization of the Average Dipole Orientation Theory: Temperature Dependence. Int. J. Mass Spectrom. Ion Phys. 1975, 17, 211-212.

36. Su, T.; Bowers, M. T. Ion-Polar Molecule Collisions. The Effect of Molecular Size on Ion-Polar Molecule Rate Constants. J. Am. Chem. Soc. 1973, 95, 7609-7610.

37. Frisch, M. J.; Trucks, G. W.; Schlegel, H. B.; Scuseria, G. E.; Robb, M. A.; Cheeseman, J. R.; Zakrzewski, V. G.; Montgomery, J. A. J.; Stratmann, R. E.; Burant, J. C.; Dapprich, S.; Millam, J. M.; Daniels, A. D.; Kudin, K. N.; Strain, M. C.; Farkas, O.; Tomasi, J.; Barone, V.; Cossi, M.; Cammi, R.; Mennucci, B.; Pomelli, C.; Adamo, C.; Clifford, S.; Ochterski, J.; Petersson, G. A.; Ayala, P. Y.; Cui, Q.; Morokuma, K.; Malick, D. K.; Rabuck, A. D.; Raghavachari, K.; Foresman, J. B.; Cioslowski, J.; Ortiz, J. V.; Stefanov, B. B.; Liu, G.; Liashenko, A.; Piskorz, P.; Komaromi, I.; Gomperts, R.; Martin, R. L.; Fox, D. J.; Keith, T.; Al-Laham, M. A.; Peng, C. Y.; Nanayakkara, A.; Gonzalez, C.; Challacombe, M.; Gill, P. M. W.; Johnson, B.;
Chen, W.; Wong, M. W.; Andres, J. L.; Head-Gordon, M.; Replogle, E. S.; Pople, J. A. Gaussian 98, Revision A.5; Gaussian, Inc.: Pittsburgh, PA, 1998.

38. Jackson, G. P.; Gibson, J. K.; Duckworth, D. C. Gas-Phase Reactions of Bare and Oxo-Ligated Actinide and Lanthanide Cations with Pentamethylcyclopentadiene Studied in a Quadrupole Ion Trap Mass Spectrometer. Int. J. Mass Spectrom. 2002, 220, 419-441.

39. Jackson, G. P.; King, F. L.; Goeringer, D. E.; Duckworth, D. C. Gas-Phase Reactions of $\mathrm{U}^{+}$and $\mathrm{U}^{2+}$ with $\mathrm{O}_{2}$ and $\mathrm{H}_{2} \mathrm{O}$ in a Quadrupole Ion Trap. J. Phys. Chem. A 2002, 106, 7788-7794.

40. Nguyen-Trung, C.; Begun, G. M.; Palmer, D. A. Aqueous Uranium Complexes. 2. Raman-Spectroscopic Study of the Complex-Formation of the Dioxouranium(Vi) Ion with a Variety of Inorganic and Organic-Ligands. Inorg. Chem. 1992, 31, 5280-5287.

41. Denning, R. G. Electronic Structure and Bonding in Actinyl Ions. Struct. Bond. 1992, 79, 215-276.

42. Vallet, V.; Wahlgren, U.; Schimmelpfennig, B.; Moll, H.; Szabo, Z.; Grenthe, I. Solvent Effects on Uranium(VI) Fluoride and Hydroxide Complexes Studied by EXAFS and Quantum Chemistry. Inorg. Chem. 2001, 40, 3516-3525.

43. Marinelli, P. J.; Squires, R. R. Sequential Solvation of Atomic Transition-Metal Ions $>195>$ the Second Solvent Molecule Can Bind More Strongly than the First. J. Am. Chem. Soc. 1989, 111, 4101-4103.

44. Magnera, T. F.; David, D. E.; Stulik, D.; Orth, R. G.; Jonkman, H. T.; Michl, J. Production of Hydrated Metal-Ions by Fast Ion or Atom Beam Sputtering-Collision-Induced Dissociation and Successive Hydration Energies of Gaseous $\mathrm{Cu}+$ with 1-4 Water-Molecules. J. Am. Chem. Soc. 1989, 111, 5036-5043.

45. Magnera, T. F.; David, D. E.; Michl, J. Gas-Phase Water and Hydroxyl Binding-Energies for Monopositive First Row Transition-Metal Ions. J. Am. Chem. Soc. 1989, 111, 4100-4101.

46. Langhoff, S. R.; Bauschlicher, C. W.; Partridge, H.; Sodupe, J. Theoretical Study of One and Two Ammonia Molecules Bound to the First Row Transition Metal Ions. J. Phys. Chem. 1991, 95, 10677-10681.

47. Bauschlicher, C. W.; Langhoff, S. R.; Partridge, H. The Binding-Energies of $\mathrm{Cu}^{+}-\left(\mathrm{H}_{2} \mathrm{O}\right)_{\mathrm{n}}$ and $\mathrm{Cu}^{+}-\left(\mathrm{NH}_{3}\right)_{\mathrm{n}}(\mathrm{n}=1-4)$. J. Chem. Phys. 1991, 94, 2068-2072.

48. Walter, D.; Armentrout, P. B. Sequential Bond Dissociation Energies of $\mathrm{M}+(\mathrm{NH} 3)(\mathrm{x})(\mathrm{x}=1-4)$ for $\mathrm{M}=\mathrm{Ti}-\mathrm{Cu} . J . A m$. Chem. Soc. 1998, 120, 3176-3187.

49. Clark, D. L.; Conradson, S. D.; Donohoe, R. J.; Keogh, D. W.; Morris, D. E.; Palmer, P. D.; Rogers, R. D.; Tait, C. D. Chemical Speciation of the Uranyl Ion Under Highly Alkaline Conditions. Synthesis, Structures, and Oxo Ligand Exchange Dynamics. Inorg. Chem. 1999, 38, 1456-1466. 